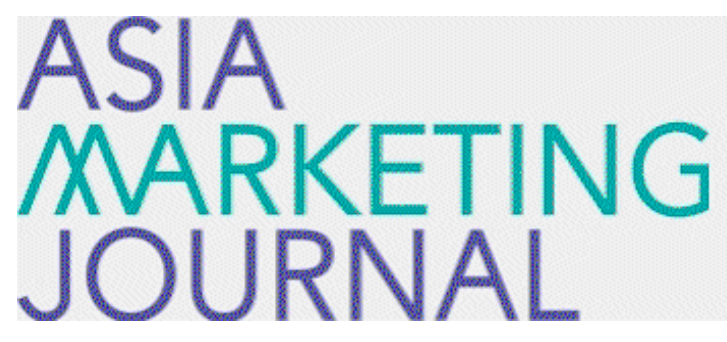

ASIA MARKETING JOURNAL

Volume 3 | Issue 1

Article 5

3-1-2001

\title{
거시환경 변화에 대응한 마케팅 전략의 수립방안
}

성태 홀

주영 김

형찬 김

Follow this and additional works at: https://amj.kma.re.kr/journal

Part of the Marketing Commons

\section{Recommended Citation}

홀, 성태; 김, 주영; and 김, 형찬 (2001) "거시환경 변화에 대응한 마케팅 전략의 수립방안," Asia Marketing Journal: Vol. 3 : Iss. 1 , Article 5.

Available at: https://doi.org/10.53728/2765-6500.1059

This Article is brought to you for free and open access by Asia Marketing Journal. It has been accepted for inclusion in Asia Marketing Journal by an authorized editor of Asia Marketing Journal. 


\title{
거시환경 변화에 대응한 마케팅 전략의 수립방안 \\ : 에스콰이아의 사례*
}

\section{Formation of Marketing Strategy for the Change of Macro-Environment: Case of Esquire}

\author{
홍성태 (한양대학교 경영학부 교수) \\ hongst@hanyang.ac.kr \\ 김주영 (국민대학교 경상대학 조교수) \\ jkim@kmu.kookmin.ac.kr
}

김형찬( (주)에스콰이아 기획담당 이사)

\footnotetext{
* 2001년도 마케팅 프로티어상 수상기업 사례연구

본 논문의 작성과 검토에 도움을 주신 메타비경영연구원의 최수호이사님께 감사드리며,

두 번째 연구자는 BK21 핵심과제에서 지원을 받았습니다.
} 


\section{사례를 시작하며}

에스콰이아는 1961년에 창업하여 국내 제화산업의 역사를 주도하고 있는 대표적인 기업으로, 우리나라 소비자들의 미적 감각과 패션을 리드하고 있는 패션기업이면서 동시에 인문사회과학분야에서 우리나라 대표적인 자료의 보고인 사회과학도서관등을 운영하는 인표재단의 모태기업이다. 지난 40년 간 에스콰이아는 사회경제적 변화와 더불어 기업의 기본을 견지하면서 적절한 시기에 탄력적인 변화를 통해 기업을 성장 시켜왔다. 특히 패션산업의 가장 큰 위기였던 I MF를 겪으면서 이를 오히려 전화위복의 기회로 활용하였다. IMF 직전까지 에스콰이아는 양적 성장을 위하여 상품권 매출 규모를 신장시키는 과정에서 패션제품으로서의 진정한 경쟁력을 많이 상실하였다. 그러나 IMF 직전부터 시작한 개혁과 변화를 통해 IMF이후에 새로운 모습으로 전환을 시도하였으며, 현재 좋은 성과를 보이고 있다. 본 사례는 이러한 에스콰이아의 전략적 변화과정과 그 성과를 보여주고자 한다.

\section{1. 변화가 요구되는 에스콰이아}

( 주) 에스콰이아는 1961년 9월에 창립된 이후에 인간중심의 경영과 멋을 겸비한 품질로 제화를 근간으로 한 가죽잡화시장의 대표적인 브랜드로 성장해왔다. 그러나 1990년대부터 본격적으로 시작된 상품권판매를 통한 규모의 성장에 힘을 기울이다가, 95년 이후 매출정체를 비롯한 성장과 경쟁력의 한계를 극복하기 위해 97 년도 초부터 새로운 변화를 모색하게 되었다.

\section{1. 에스콰이아의 간략한 역사}

탁월한 미적감각을 바탕으로한 수제화로 시작하여 공장생산을 통해 기성화시장을 개척한 에스콰이아 변천사를 보면 아래 [표1]과 같이 크게 창업기, 도약기, 외적성장기, 정체기로 나누어 볼 수 있다.

창업기에는 우수한 제품은 생산만 된다면 얼마든지 판매할 수 있는 시기였으며 에스콰이아는 확고한 제품경쟁력을 보유하고 있었다. 도약기에는 생산시설의 확충과 전국적인 유통망 확보를 근간으로 하는 새로운 경쟁력을 확보하려고 노력했으며, 외적성장기에는 제화이외에 의류를 추가하면서 본격적인 패션 전문업체로 성장하였다. 그 당시의 국내산업환경이 성장이 최우선적인 경영목표로서 받아들여졌기 때문에, 에스콰이아도 유통력을 밑바탕으로 패션과 양적성장이라는 두 마리 토끼를 쫓게 되었다. 정체기로 접어들면서 제화 및 패션산업의 경쟁강도가 증가하고 시장성장율이 둔화됨에 따라 에스콰이아는 잠재되어 있던 다양한 문제점들이 수면위로 떠오르게 되었다. 


\begin{tabular}{|c|c|c|c|c|}
\hline & $\begin{array}{l}\text { 창업기 } \\
61-72\end{array}$ & $\begin{array}{l}\text { 도약기 } \\
73-86\end{array}$ & $\begin{array}{c}\text { 외적성장기 } \\
87-93\end{array}$ & $\begin{array}{l}\text { 정체기 } \\
94-97\end{array}$ \\
\hline $\begin{array}{l}\text { 핵심적 } \\
\text { 환경특성 }\end{array}$ & 수요초과시기 & $\begin{array}{l}\text { 경제고속성장 } \\
\text { 제화업계성장 } \\
\text { 컬러TV } \\
\text { 교복자율화 }\end{array}$ & $\begin{array}{l}\text { 88올림픽 } \\
\text { 내셔널브랜드 } \\
\text { 활성화 } \\
\text { 신세대 출현 }\end{array}$ & $\begin{array}{l}\text { 내수시장 경쟁심화 } \\
\text { 시장개방 } \\
\text { 상품권양성화 }\end{array}$ \\
\hline $\begin{array}{l}\text { 중점과제 } \\
\text { 및 목표 }\end{array}$ & $\begin{array}{l}\text { 생산력증대 } \\
\text { 고급제품생산 } \\
\text { 공장건립 }\end{array}$ & $\begin{array}{l}\text { 대량생산 } \\
\text { 유통망확대 }\end{array}$ & $\begin{array}{l}\text { 패션전문업체 } \\
\text { 소비패턴 변화에 } \\
\text { 대응하는 } \\
\text { 경영합리화 }\end{array}$ & $\begin{array}{l}\text { 토탈패션업체 } \\
\text { 질적성장 } \\
\text { 고객지향경영 }\end{array}$ \\
\hline 성과 & $\begin{array}{l}\text { 기업역량을 } \\
\text { 생산에 집중 }\end{array}$ & $\begin{array}{l}\text { 유통망 } \quad 84 \text { 개로 } \\
\text { 확대 } \\
\text { 지방으로 진출 }\end{array}$ & $\begin{array}{l}\text { 의류사업시작 } \\
\text { 마케팅개념 도입 } \\
\text { 브랜드 다양화 } \\
\text { 상품권매출성장 } \\
\text { Push마케팅 }\end{array}$ & $\begin{array}{l}\text { 의류사업 정착 } \\
\text { 그룹체계 도입 } \\
\text { 해외공장 및 매장운영 }\end{array}$ \\
\hline 개선과제 & & & $\begin{array}{l}\text { 경영목표는 } \\
\text { 고객중심, } \\
\text { 품질향상이나 } \quad \text { 양적 } \\
\text { 성장에 전념 }\end{array}$ & \begin{tabular}{|l} 
상품권판매에 집중 \\
매출정체 \\
수익성악화 \\
제품경쟁력약화 \\
대기업문제점 발생
\end{tabular} \\
\hline
\end{tabular}

\section{2. 현황분석}

\subsection{1. 산업의 일반 현황}

90년대 중반이후 제화시장의 고객은 선택 기준이 메이커가 아니라 브랜드로 변화되었다. 시장 또한 고가시장과 중저가시장으로 양극화 되어가고, 경쟁측면에서도 제화 3 사의 경쟁에서 싸롱화 및 수입브랜드의 도입에 따른 다변화된 브랜드 경쟁으로 변화되었다. 에스콰이아를 포함한 제화3사는 소비자, 경쟁, 브랜드 환경변화로 인해 첨단 패션시장에서 경쟁력을 상실하였다.

공급측면에서 보면 제화산업은 저부가가치의 노동집약적인 3D 산업으로 90년대 초반부터 기능공 양성이 부진하여 자가 생산이 한계에 부딪혔다. 가격과 비용, 원부자재 의존도 등을 감안하여 볼 때 해외나 외부의 out sourcing이 선호되어서 중국등으로의 진출이 활발해 지는 등 생산구조도 변화되어 갔다.

\subsection{2. 에스콰이아 성과추이 분석}

에스콰이아의 성과추이를 보면 그룹전체의 매출이 94년을 기점으로 감소추세에 진입했고, 매출액 대비 판매관리비의 비중이 점차 증가하여 96 년도에는 $43 \%$ 에 달하였다. 효율성 
측면에서도 인당매출액과 점당매출액이 94년에 급격히 감소하였으며, 그 이후에도 개선되지 않았다. 이러한 수치는 경쟁사들과 비교했을때도 좋은 수준은 아니었다 (그림1,2참조).

\section{[그림1] 그룹 성장 추이 - 매출수량}

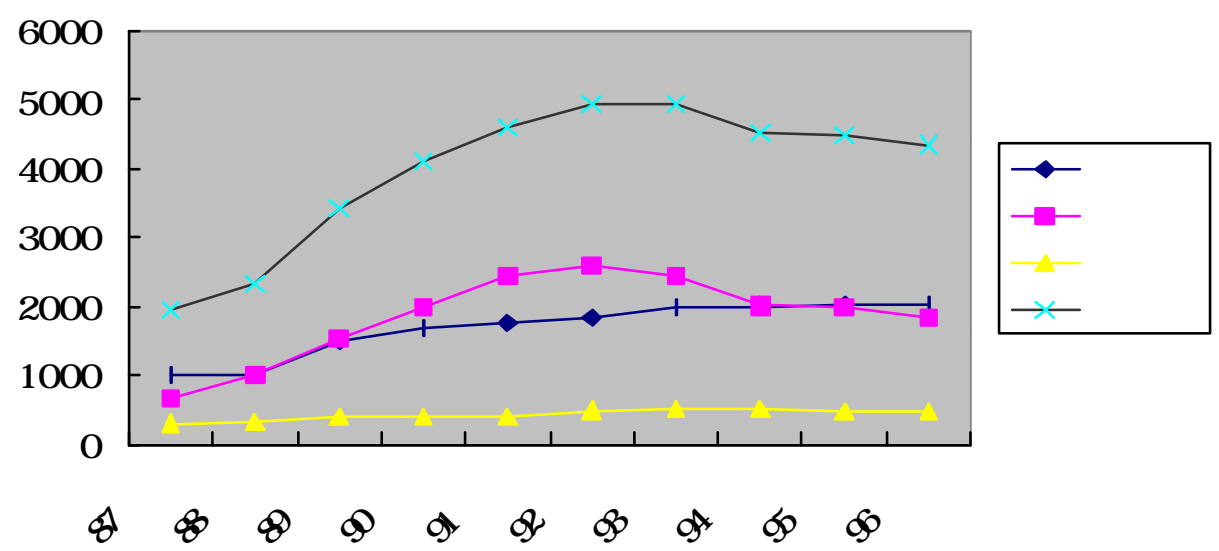

에스콰이아의 매출을 꾸준히 신장될 때는 효율성이나 판매관리비의 증가가 상대적으로 문제가 되지 않으나, 성장이 둔화되는 시점부터 그동안 경시했던 효율성과 비용의 압박이 증가되고 이에 따라서 수익성이 악화되었다.

매출 정체는 생산성 측면에서도 문제를 야기시켰다. 판매 부진에 따른 가동율 저하로 인해 비용이 증가하였다. 더 커다란 문제는 비용절감을 위해 가동율이 보장되는 제품을 우선 생산하게 되고, 패션성이 뛰어난 제품이거나, 전년과 다른 디자인인 경우에는 생산이 늦어져서 고객이 원하는 시기에 적기시에 매장에서 판매되기가 힘들어졌다. 따라서 주요경쟁사로 등장한 싸롱화업체들에게 상당한 시장을 내주게 되었다.

\section{[그림2] 그룹 효율성 추이 - 인당 매출량}

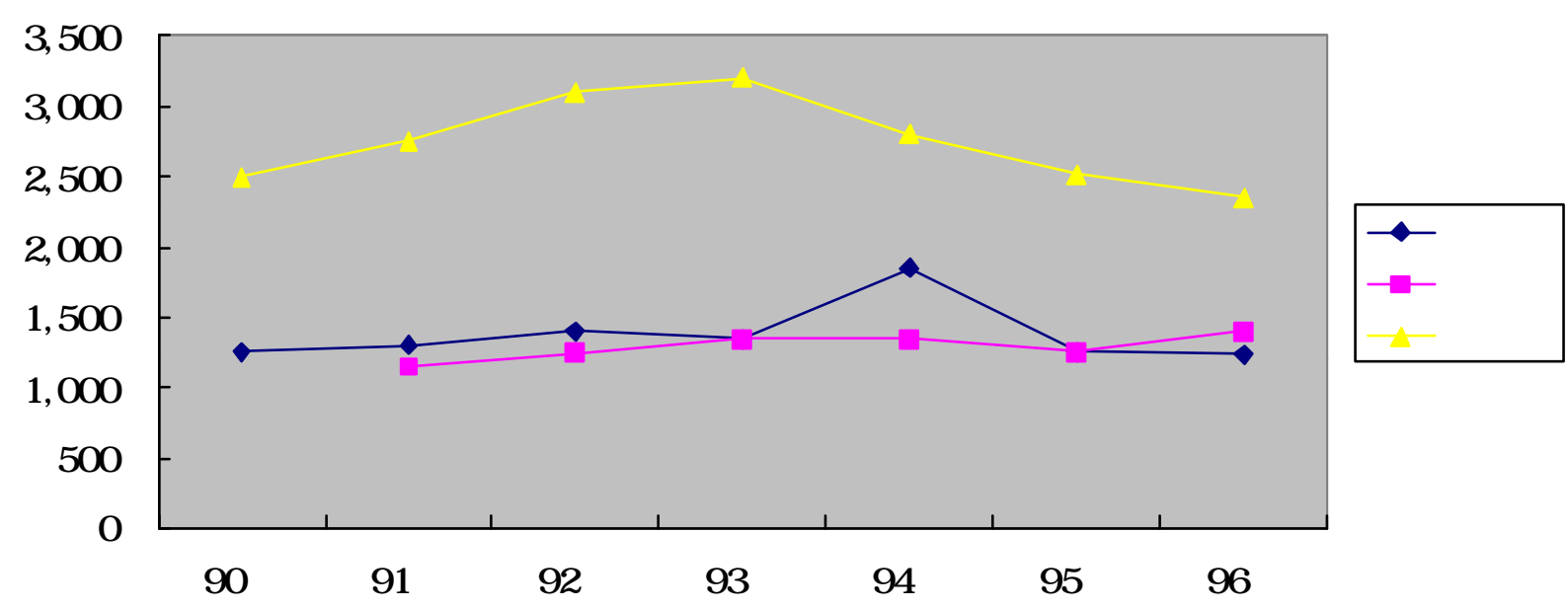


1. 2. 3. 소비자 인식조사

소비자의 인식을 보면 경쟁회사나 경쟁제품 중에서 에스콰이아에 대한 인식이 악화되고 있었다. 80년대 특히 여화의 경우에는 국내의 대표브랜드로서 인식되었으나, 96년도 조사에 따르면 소비자의 상표선호도가 5위에 불과하였다.

[그림3] 소비자 상표 선호도 - 제화/캐주얼 96년 베스트 브랜드

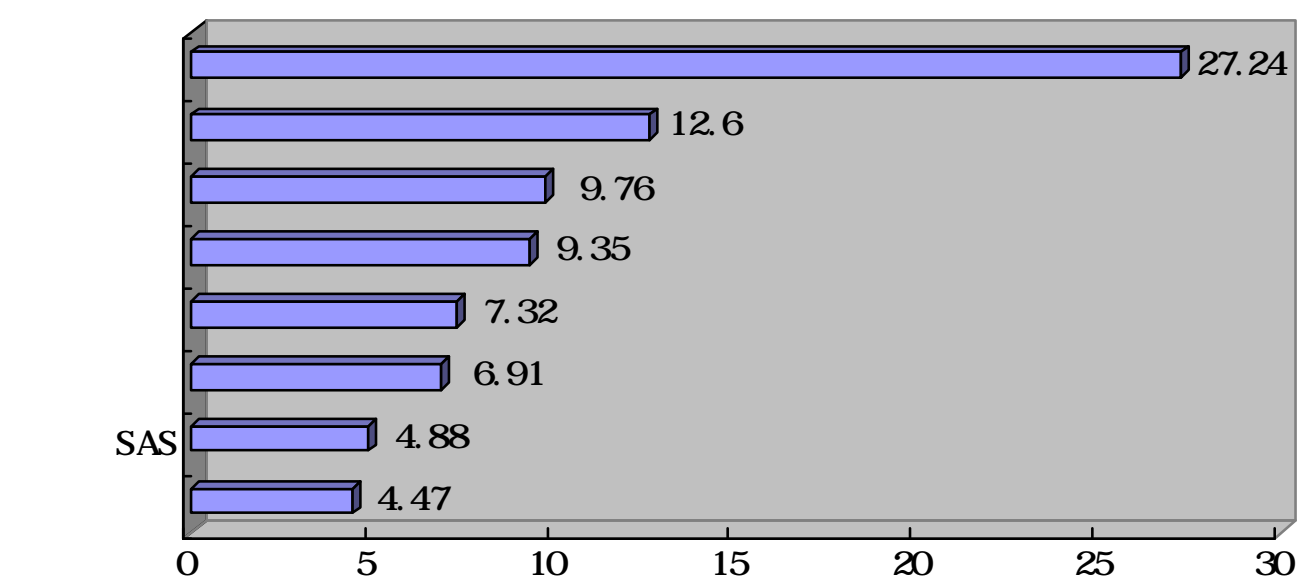

또한 에스콰이아 매장에 입점 고객들 중에서 젊은 층의 비중이 점차 감소하였으며, 다양한 형태의 불만이 증가하고 있었다. 97년 조사결과를 보면 브랜드의 이미지 타겟과 실제구매고객의 연령층을 보면 실제 구매 고객층이 점차 넓어지는 것을 볼 수 있다. 특히 대표브랜드가 아닌 포트폴리오나 패션리더 등과 같은 젊은층대상의 브랜드에서 실제구매층이 넓어지는 현상은 패션회사로서 바람직한 방향이 아니었다. [그림4]에서 보듯이 대표브랜드의 경우에 원래의 이미지 타겟보다 젊은 층들이 구매하는 것을 볼 수 있는데 이는 선물로 받은 상품권을 소진하기 위해서 자신의 이미지에 맞지 않지만 구매하는 경우가 많았기 때문이다.

남녀비율로 보면 여성고객의 경우에 불만이 더 많았고, 남성의 경우에는 약 $70 \%$ 에 해당하는 고객들이 에스콰이아에 충성도를 보였다. 하지만 전반적인 만족도는 그다지 높지 않은 수준이었다. 
[그림4] 브랜드 타겟과 실제 구매고객

(여)

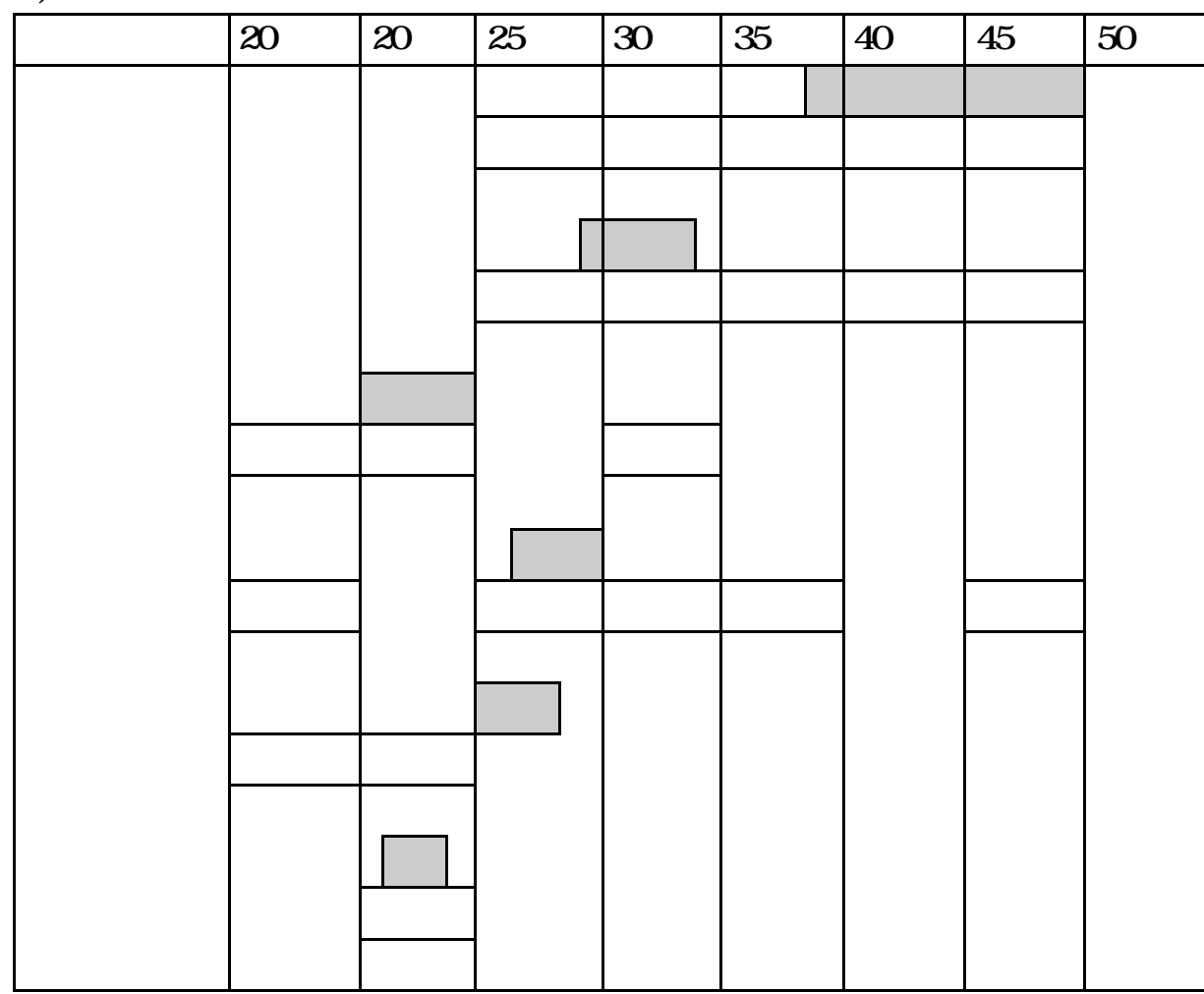

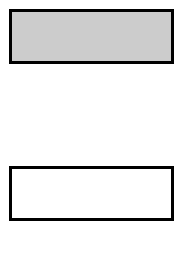

( 남)

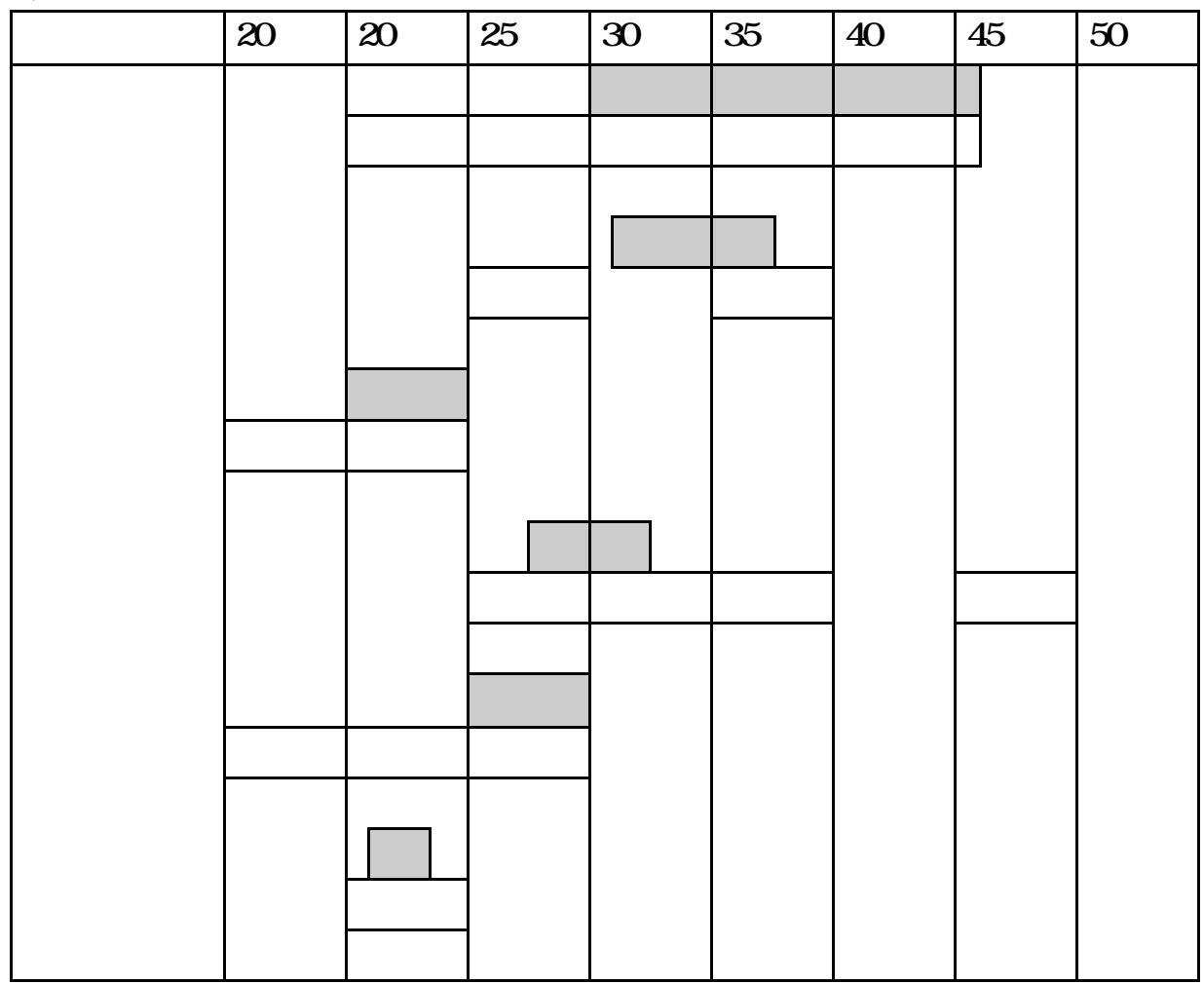




\section{2. 4. 종업원 의식분석}

회사직원들의 의식을 조사해본 결과, 회사의 사업도메인에 대하여 1 위가 구두의류제조 판매회사, 2위가 토탈패션회사, 3위가 상품권판매회사, 4위가 유통(영업) 회사로 나타났으며 이는 구성원들의 생각이 하나로 일치되고 있지 못하다는 것을 보여주는 것이었다. 또한 상품권판매회사라는 인식이 회사전반에 폭넓게 잠재되어있었으며, 이는 직원들은 본업이외에 상품권시즌이 되면 모두가 상품권을 판매하여야 하는 부담을 갖고 있기 때문이었다.

이직율을 보면 산업평균이나 경쟁사와 유사한 수준이나 96년도의 신입직원의 경우에는 조금 높은 수치를 보였다. 하지만 전반적으로 회사의 기본경영이념처럼 인간적이라고 생각하고 있고, 특히 오너의 도덕성이나 성실성에 대한 믿음은 강했다. 반면 오랜 역사를 가지고 있었기 때문에 관료적인 의사결정에 대한 불만도 있었으며, 앞으로는 진취적이 되어야 한다고 생각하고 있었다.

\section{2. 5. 매장분석}

패션산업 전반적으로 유통구조상 Road- shop이 퇴조하는 반면, 백화점이 성장하고, 중저가 할인점이 활성화되는 추세였으나, 에스콰이아는 백화점 성장에 대한 대응이 미흡하여 백화점 내 입지가 약화되었고, 손익구조 악화에 따른 대리점 이탈현상도 나타나고 있었다. 소비자들의 매장에 대한 평가도 마음에 드는 제품을 구매하는 장소가 아니라, 미리 사놓은 상품권으로 제품을 교환하는 장소로 인식하게 되었다. 매장 직원의 입장에서도 살 것이 분명한 고객에게 최선을 다할 필요성을 느끼지 못하게 됨에 따라서 판매전문성이나 친절면에서 부족한 점이 드러났다. 또한 매장영업관리도 전산화를 포함한 관리기법이 신속한 진열과 재고 순환 그리고 다양한 지불수단(현금, 상품권, 카드, 훼미리카드등)에 비하여 효율적이지 못하였다.

\section{2. 에스콰이아의 의사결정}

97년 당시의 현상을 종합하면, 지속적인 성장위주의 전략의 축으로 활용한 상품권 판매에 의한 매출 의존도 심화로 인하여 고객 니즈와 경쟁환경 변화에 신속한 대응이 이루어지지 못하고, 브랜드 가치 제고 노력이 미흡함에 따라 수익성이 악화되고 있었고, 유통변화에 대한 대응 미흡으로 유통력 약화가 동시에 발생한 상황이었다.

\section{1. 에스콰이아의 전략방향 대안들}

이러한 상황을 탈피하기 위하여 에스콰이아는 크게 두 가지의 전략방향을 선택할 수 있다. 하나는 매출 및 이익제고전략이고 다른 하나는 패션성 중심의 차별화 전략이다.

매출 및 이익제고전략은 성장을 계속하기 위한 전략으로서 매출규모 성장과 더불어 생산효율성을 담보함과 동시에 더욱 넓은 유통 커버리지를 확보하는 것을 의미한다. 차별화 전략은 무조건적인 이익이나 매출 증대가 아니라 패션업의 기본이 되는 차별화된 패션성을 
중심으로 브랜드 파워를 확보하여 규모보다는 효율성과 장기적인 경쟁력 확보를 위한 전략방향이다.

그러나 이러한 두 가지 전략방향은 서로 상충되는 면을 가지고 있다. 즉 매출을 증대시키고 이익을 확보하기 위해서는 매출 및 이익관리와 생산관리에 치중해야 하는 반면, 이를 위해서는 차별적인 패션성을 위한 제품 혹은 브랜드육성과 매장관리를 포기해야 하는 의사결정을 필요로 했다. 꾸준하게 한 성장가도를 달려온 에스콰이아는 실질적으로 매출 및 이익관리중점의 전략을 구사함에 따라 차별적인 패션성을 상당부분 상실했었다.

그러나 변화된 시장과 소비자들은 패션성을 상실한 기업에게 더 이상의 매출을 일으켜주지 못했기 때문에, 에스콰이아의 경쟁력은 점차로 약화되어 가고 있었다. 제화업체로서의 패션성은 매출을 위한 필요조건이나, 패션경쟁력이 약화된 에스콰이아는 강력한 상품권 판매 드라이브를 통해 매출과 이익을 보전하고 있는 상황이었다.

\section{2. 상품권분석}

효과적인 전략 설계를 위해 심도 있는 상품권 분석이 이루어졌다. 상품권은 60 년대 선물용으로 정부가 업종별로 지정함으로써 도입되었다. 소비자는 선물로, 실제 물건이 아닌 상품권을 사용함으로서 편리성을 도모했고, 기업 또한 제품 판매 이전에 현금을 확보할 수 있으므로 기업에게도 상당한 이점을 가져다 주었다.

그러나 동전의 양면처럼 상품권은 에스콰이아에게 상당한 부담으로 작용하게 됬다. 에스콰이아의 상품권 의존도가 점진적으로 증가하여 매출의 $80 \%$ 를 차지하였으나, 90 대 중반이후 제화 상품권 시장은 정체 및 감소되는 경향을 보였다. 신세대층이 상품권을 외면하였으며, 일반 소비자들은 제화 상품권 대신 선택의 폭이 넓은 백화점 상품권을 선호하는 것이 그 이유였다.

97년 상품권 시장규모는 19,211 억원 중에서 제화상품권은 8,100 억원 백화점상품권은 7,026 억원이었고 기타 유류 및 의류 등이 $21 \%$ 를 차지하였다. 그러나 I MF의 영향으로 98 년 기준 제화상품권은 23. $1 \%$ 감소 그리고 백화점 상품권은 2. $2 \%$ 감소가 예상되어 백화점상품권이 시장을 주도하게 될 것으로 예상되었다.

상품권 판매로 인해 판매 당시 자금흐름은 좋았으나, 세일과 상품권 할인으로 인해서 손익구조는 악화되었다. 제화의 경우 상품권의 매출비중은 전체의 $70 \%$ 수준이었으며, 상품권으로 인한 회사 내부의 관리체계상에서의 오류액수도 190 억 정도에 달하였다. 매출의 많은 부분을 의존하고 있는 상품권이 없어진다면 지속적인 감소추세인 매출규모에 상당한 타격을 가할 것으로 보이며 $\mathrm{IMF}$ 를 감안한다면 회사의 정상운영이 힘들 정도의 상황이었다. 게다가 에스콰이아가 상품권 의존도 심화의 영향으로 고객의 기호를 등한시하게 되었다는 것이 문제였다. 선물용으로 상품권이 팔리면 자동적으로 제품 판매가 이루가 이루어지므로, 타겟고객의 욕구를 면밀히 파악하지 않게 되고 이에 따라 디자인과 소재 역시 좋은 평가를 받지 못하였다. 더욱이 6개월 전에 다음 시즌의 유행, 색상, 디자인을 기획하는 기획생산 체제인 에스콰이아는 Trend 에 대한 반응이 느렸으며, 예측이 실패할 경우 상당한 재고를 부담하여야 했다. 


\section{3. 에스콰이아의 해결방안들}

이러한 상황에서 에스콰이아가 헤쳐나가야 할 길은 매우 급박하고 힘든 길이었다. I MF라는 힘든 경제상황과 이에 따른 매출한계 그리고 다양한 내부 문제점들이 지속적으로 표출되었으며, 전략적으로도 에스콰이아가 지향해야 하는 패션전문회사라는 목표도 달성하기 어려운 상황이 중첩되어 에스콰이아를 짓누르고 있었다.

이같이 어려운 환경에서 에스콰이아가 선택할 수 있는 대안들은 아래와 같이 정리할 수 있었다.

* 감원: I MF시대에 어느 기업이나 선택할 수밖에 없었던 비용절감 방안이다. 하지만 감원으로 인한 조직력의 약화와 포기해야 하는 필수적인 활동들을 감수해야만 하고, 당시 노조 문제도 발생할 수 있었다.

* 브랜드 축소: 매출 감소에 따라 수익이 나지 않는 브랜드를 철수하고 그에 따른 비용을 절감하는 대안이다. 그러나 에스콰이아가 추구하고 있었던 패션성을 일정부분 포기해야했으며, 이에 따라 이미지의 손상과 브랜드파워의 상실을 감수해야 하는 대안이었다.

* 매장정리: 유통은 마케팅 믹스 중에서 가장 융통성이 적고, 많은 시간과 비용을 필요로 하는 마케팅도구이다. 백화점, 직영점이나 대리점들 중에서 손익이 맞지 않는 매장을 정리하고 운영방식을 shop-master방식으로 전환하는데에는 적지않은 관계자의 반발과 법적인 문제, 모험들이 수반되었다. 또 한번 정리한 매장은 나중에 다시 신설하기 위해서는 상당한 비용과 시간이 소요되므로 어려운 의사결정이었다. 전국망을 유지하면서 경쟁자와 유통 커버리지에서 우위를 유지하기 위해서 매장정리는 선택하기 어려운 방법이다.

* 상품권축소: 상품권매출이 전체의 $70 \%$ 가 되는 시점에서 상품권을 포기하거나 축소한다는 것은 즉각적인 매출감소와 현금흐름의 악화를 가져오는 것이었다. 앞서 분석에서도 보았듯이 상품권의존도가 많은 문제를 가져오고 있기는 하지만 10년 가까이 조금씩 증가한 의존도를 조직에서 없앤다는 것은 I MF와 같이 한치 앞을 내다보기 힘든 경제상황에서 현실성이 적은 대안이지만 회사조직에 패션이라는 본질을 정립하는데 에는 필요한 대안이었다.

* 공장정리 및 외주생산: 가동률이 떨어지고 싸롱화에 비해서 기간도 오래 걸리는 공장을 정리하고 외주생산만을 하는 대안이다. 공장에서의 자가생산은 제화가 가지고 있는 패션성을 뒷받침해주고 편안함이나 견고성을 보장해주는 역할을 하고 있었으며, 그 외에도 해외생산을 위한 기술연구소의 기능을 수행하고 있었다. 공장을 정리하면 적지않은 고정비절감효과와 신속한 생산을 얻을 수 있겠지만 에스콰이아의 인간중심경영 차원과 핵심기술력의 유지 강화라는 측면에서 쉽게 선택할 수 있는 대안은 아니었다.

* 고객명확화: 고객의 명확화란 매출신장을 목적으로 상품권을 통해서 광범위하게 형성되어있던 고객층을 좁히고 타겟을 명확하게 하는 것을 의미한다. 즉 누구나 구매할 수 있게 하기 위해서 사용되던 비효율적인 마케팅비용을 줄이고 한정된 고객을 대상으로 전문적인 패션성을 살리고 효율성을 높이는 제살깍기 
작업이라고 할 수 있다.

에스콰이아를 비롯해서 많은 회사들이 이런 작업을 시도하고 있었지만 항상 이론보다는 영업의 요구에 의해서 실제로 실행되기 어려운 구호에 그치는 전략대안이었다.

에스콰이아의 입장에서 위의 대안들 중에서 어떤 것을 선택하여 할 것이며 또 어느정도 철두철미하게 진행할 것이고, 어떤 순서대로 진행할 것인가를 결정해야 했다. 에스콰이아는 결과적으로 위의 가능한 모든 대안들을 선택하였고 그대로 실행하였다. 물론 이런 구조조정 대안 이외에도 경영혁신노력과 고통분담노력등도 동시에 실행되어 졌다.

시기적으로 보면 브랜드축소와 이에 따른 인력 축소가 선행되었으며, 매장정리, 고객명확화, 상품권축소 및 외주생산이 후속조치로 실행되어 졌다. 실행정도면에서 보면 브랜드는 제화 이외에 보유하고 있던 대부분의 의류브랜드들과 라이센스 브랜드를 주로 정리하였으며, 자체소유 매장을 임대매장등으로 전환하였으며, 공장은 해외영업의 전진기지화를 시도하였다. 실행정도면에서 가장 노력을 기울인 것은 고객명확화와 이에 따른 마케팅전략의 구체화라고 할 수 있다.

\section{3. 패션 전문회사로서의 에스콰이아 전략}

\section{1. 마케팅전략의 큰 방향}

어려운 변혁기를 통과하고 나서 에스콰이아가 궁극적으로 바라는 미래상은 패션전문회사이었으며, 전환과정은 매출 성장으로 비대하여진 몸을 가볍게 하여 새로운 시대에 적합한 기업이 되는 것이었다. 이런 측면에서 보면 고객명확화에 따른 정교하고 과감한 마케팅전략은 당연하다고 볼 수 있다.

상품권 업체가 아닌 패션업체로서 고객을 확인하고, 상품권에 의해 잃어버린 고객을 되찾고, 명확한 포지셔닝, 브랜드 파워를 증진하기 위해서 다음과 같은 전략을 실행하였다.

\section{2. 목표시장선정}

우선, 목표시장을 재점검하기 위해서 경쟁자를 싸롱화, Nati onal, 중저가 브랜드 등으로 세분화하여 경쟁자를 재확인하였다. 그 후에 현재 20대 초- 20대 중반 감각 추구형의 싸롱화 주고객, 20대 후반-30대 중반 패션 추구형의 제화3사와 싸롱화 혼재고객, 30대 후반-50대 제화3사 classic 추구고객으로 고객을 삼분화하였다. 
[표1] 목표시장 선정
A 20대 초 2애 중반
싸롱화 주고객
<감각 추구형>
B 20대 후 3애 초반
제화 3사 / 싸롱화 혼재
$<$ Fashi on Mass>
C 30대 후 5애
제화 3 사 주고객
$<\mathrm{Cl}$ assi c Mass $>$

이 중 에스콰이아는 20 대- 30 대 초반의 고객을 타겟으로 정하고, 싸롱화와 Nati onal 브랜드의 틈새를 주 시장으로 선정했다. 에스콰이아의 입장에서 20 대 고객들이 원하는 다양하고 튀는 디자인 선호를 신속하게 대응할 수 있는 능력이 싸롱화에 비해서 약했으며, 이 고객들은 회사 및 브랜드에 대한 충성도나 인지도가 안정적이지 못하였다. 30대 후반의 시장은 에스콰이아가 지향하고 있는 패션성이나 Trend를 요구하고 있지 않았다. 따라서 Fashi on Mass라고 명명한 20대 후 - 30대 초의 고객들을 타겟으로 정했으며, 이들의 요구사항과 감각에 적합한 세부 타겟명확화를 시도하였다.

\section{[그림5] 기회시장의 포착}

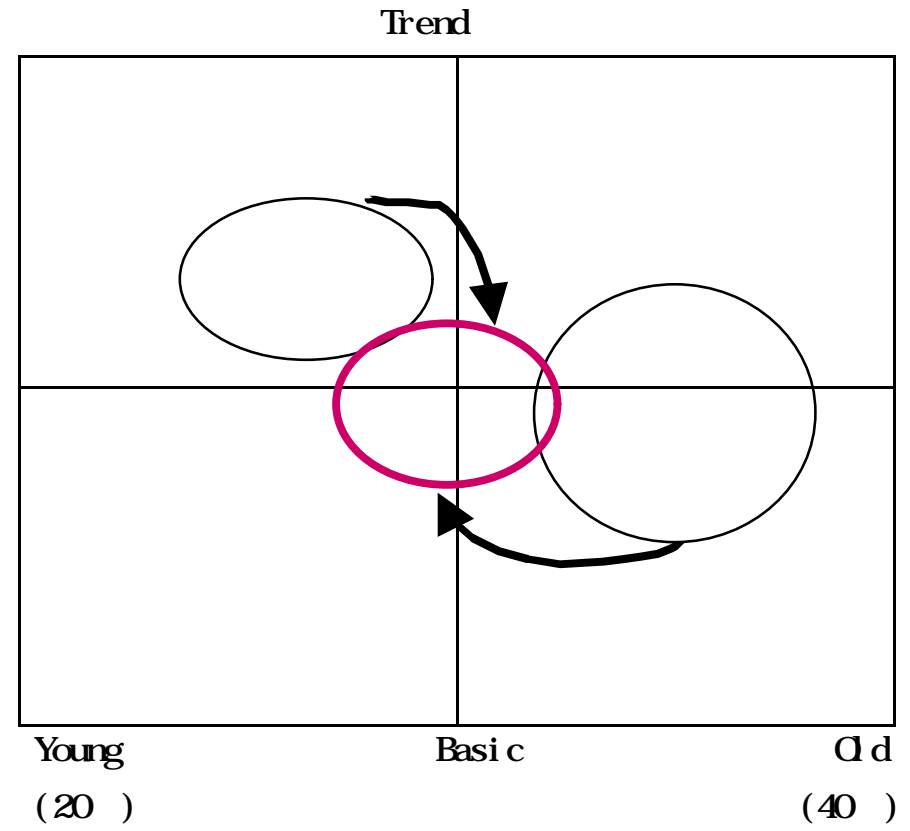

고객의 명확화에서 가장 중요한 요소는 자신들이 선택한 고객이 아닌 경우에는 판매를 하려고 노력하지 않고 포기하는 것이다. 상품기획, 생산, 영업에서 이러한 제살깍기 과정을 거침으로서 실질적으로 가능한 타겟마케팅이 될 수 있었다. 타겟고객에 대한 적극적인 마케팅과 홍보로서 고객만족을 이끌어내어서 재구매율을 높이는 것을 시장점유율보다 우선적으로 생각하였다. 


\section{3. 제품전략}

에스콰이아를 패션전문회사로 재정립하기 위해 제품전략을 수립하였다. 제품전략의 주요 이슈는 선택과 집중이었다. 에스콰이아는 브랜드에 중점을 두고, 타겟을 좁고 깊게 정하기로 하였다. 하나의 구두 스타일, 즉 아이템별 매출을 제한하는 대신 멀티 아이템을 기획하였다. 이로서 동일한 모양의 구두가 많이 팔리는 대신에 여러개의 구두스타일을 기획, 디자인 제작하였다. 여러 스타일을 기획하고 판매하는 것은 하나의 스타일로 많이 파는 것에 비해서 비용은 많이 들지만 패션제품의 생명과 희소성을 높임으로서 이미지 제고에 도움이 되었다. 개념적으로 싸롱화에 비해서 품질은 우수하지만 $T r$ end는 좀 뒤떨어지게 방향을 잡았으며, 가격대는 싸롱화에 비해서 약 5만원정도 저렴하게 책정하였다.

또한 남성은 1년에 평균 1켤레를 구입하나, 여성은 1년에 2켤레 구입하므로 남성보다는 여성 위주로 제품을 구성하였고, 서울이 유행 흡수력이 크므로 지방보다는 서울에서 승부하였다. 또한 기타 액세서리 용품 또한 여성에 중점을 두었다.

[ 표 2] 제품 운영비율

\begin{tabular}{|c|c|c|}
\hline & 구두 & 핸드백· 코디 포함 \\
\hline 남 성 & $40 \%$ & $35 \%$ \\
\hline 여 성 & $60 \%$ & $65 \%$ \\
\hline
\end{tabular}

\section{4. 이미지 전략}

\section{4. 1. Cl (Cor por at e I dent i ty) 변경}

$\mathrm{Cl}$ 는 기업의 역사와 전통을 상징하는 것으로서 전통적인 유럽의 패션회사들도 최근 들어서 세계로 시장을 확장하면서 전통적인 문양들을 새로운 감각의 $\mathrm{Cl}$ 로 전환하는 경우들이 있었다. 에스콰이아는 창업이래 가져오던 $\mathrm{Cl}$ 를 가치 있다고 인식하던 세대의 연령이 높아지고, 에스콰이아의 새로운 타겟 고객들에게 어필하기 힘들어짐에 따라 $\mathrm{Cl}$ 를 변경하였다. 이러한 의사결정은 I MF를 겪으면서 쉽게 투자하기 힘든 비용이 적지 않게 수반되는 것이었다.

[ 그림 6] 에스콰이아의 $\mathrm{Cl}$ 변화
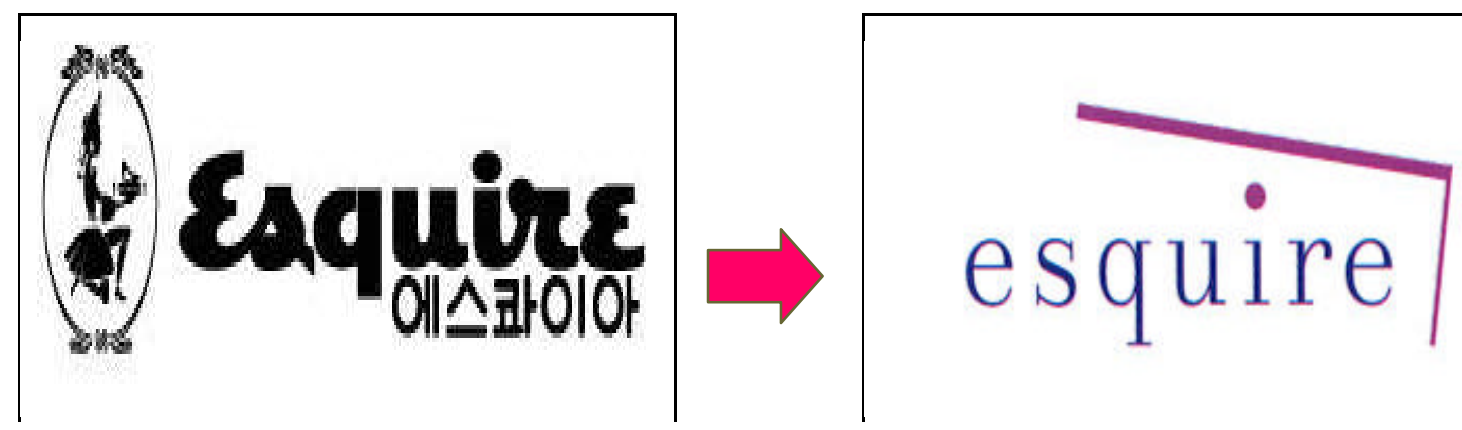


\subsection{2. 에스콰이아 40 주년 $\mathrm{enbl} \mathrm{em}$}

에스콰이아가 했었던 또 하나의 이미지 변신작업은 40주년 행사의 기획과 실행이었다. 고객에게 변화된 모습을 알리고 그 변화된 이미지를 전달하기 위해서 각종 이벤트를 실행하였으며 이것을 새로운 변화를 계속되는 것으로 굳히고자 하였다.

[ 그림 7] 에스콰이아 entbl em

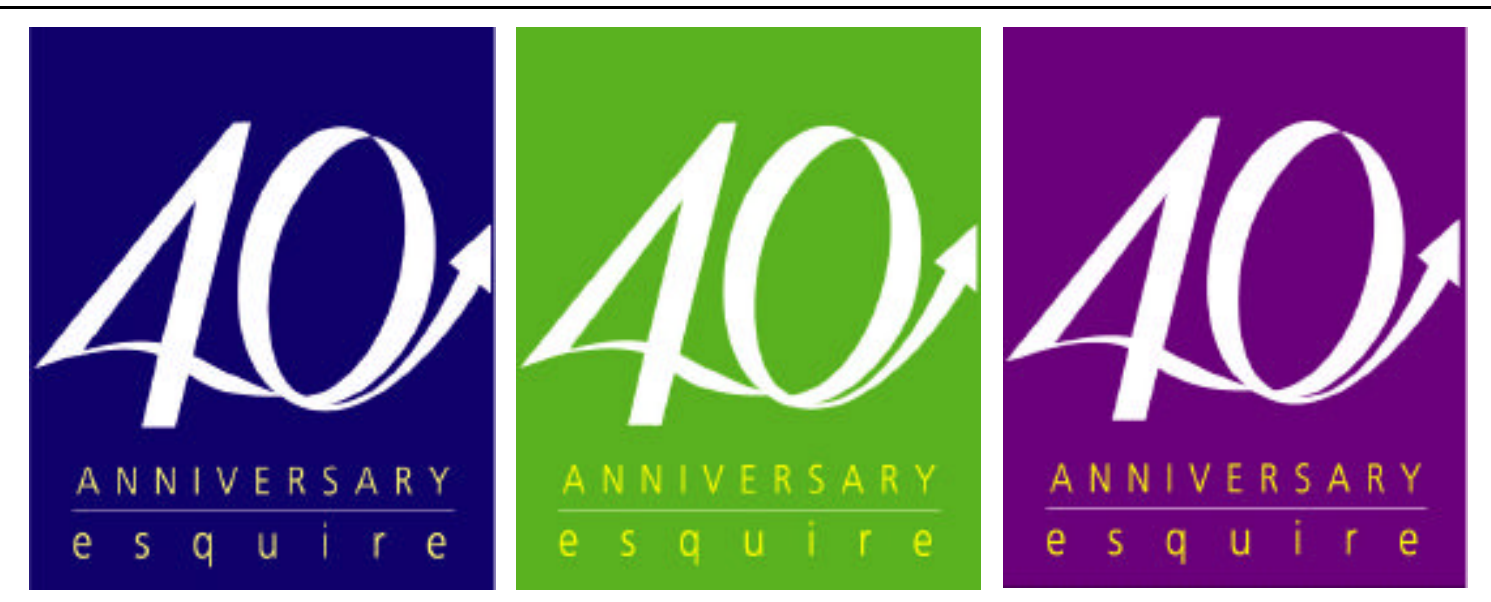

\section{5. 상품조달전략}

신속한 상품 기획으로 고객의 욕구를 충족하고 trend를 따라잡고 원가절감효과를 누리기 위해서 자체 생산 비중을 축소하는 대신 국내외 out-sourcing을 증가시켰다. 과거 자체생산 $67 \%$ 완사입(외주) $30 \%$ 해외공장 $3 \%$ 의 비중을 자체 $35 \%$ 완사입(국내외 포함) $55 \%$ 해외공장 $10 \%$ 으로 변경하였다.

완사입의 경우 원가 우위를 살리려는 동남아 사입 이외에도, 패션성을 유지강화하기 위해서 $20 \%$ 의 상품을 이태리에서 조달하고 있다.

또한 생산 방식도 탈바꿈하였다. 공장에서 일괄적으로 샘플 제작하고 관리하던 패턴(최대 180 일 소요) 은 소비자가 어떤 선택을 할 것인가에 대한 위험부담 때문에 안정적인 방향으로 가는 경향이 있었다. 즉, 새로운 trend가 아닌 이전에 유행했던 스타일을 다시 반복하는 것이었다. 그러나 월 단위 또는 격주단위의 반응생산체계로 전환하여 사전 기획에 의한 스피드 체계를 구축하여 최소 30 일에서 45 일내로 기간을 단축하여 빠르게 변화하는 고객들의 욕구에 대응하였다. 
[그림 8] 상품기획의 변화

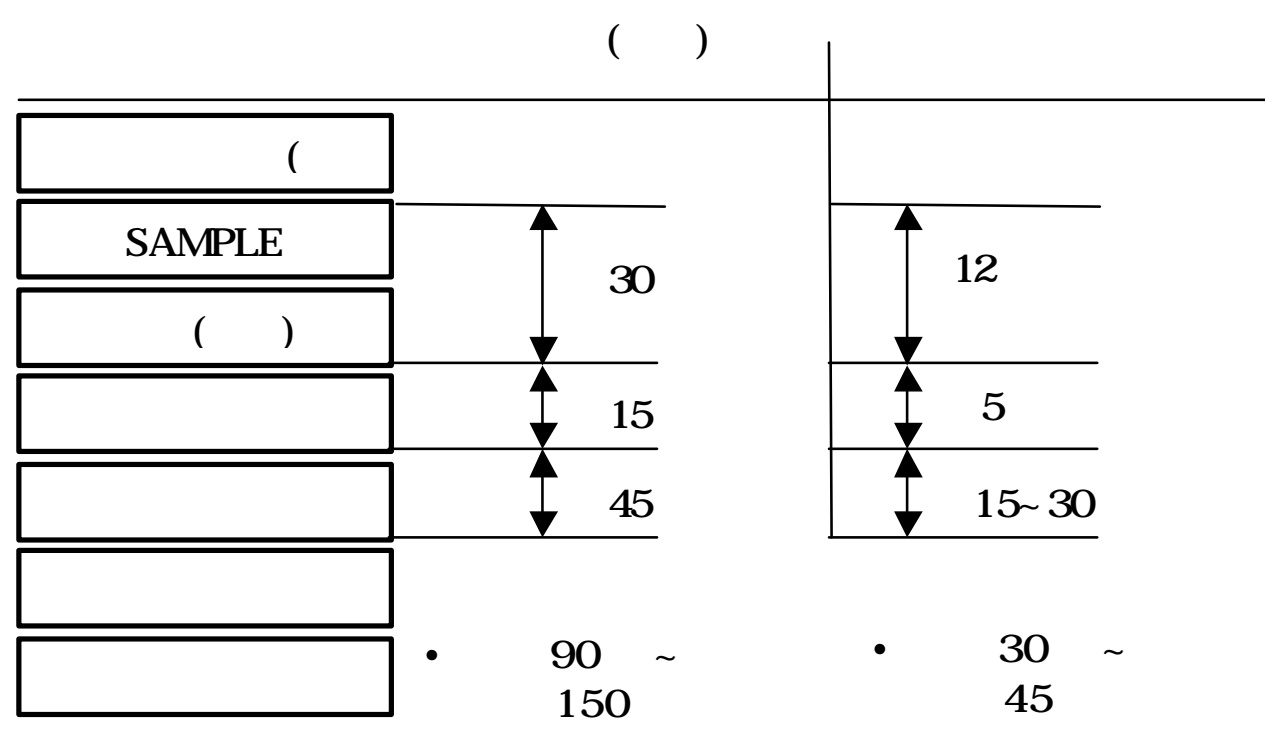

\section{6. 유통전략}

유통관리력을 강화하기 위해서 브랜드(고객)매장을 분리하여 운영하였다. 브랜드 매장을 $\mathrm{ESQ}$ 와 OutCl ass로 나누어서 서울지역에서는 백화점을 중심으로 $\mathrm{ESQ}$ 를 운영하였으며, 전국 5 대 광역시 중심으로는 $\mathrm{ESQ}$ 와 OutCl ass를 단독점과 백화점에서 균형있게 운영하였다.

[표 3] 에스콰이아 매장현황

\begin{tabular}{|c|c|c|c|}
\hline & 전체 & ESQ 27-32세) & ESQ+Outcl ass \\
\hline 단독점 & 18개 & 2개점 & 16개점 \\
\hline 백화점 & 52 개 & 30개점 & 22개점 \\
\hline & & 서울지역 중심 운영 & 전국 5대 광역시 중심 \\
\hline
\end{tabular}

그리고 백화점 변화 추세에 대응하기 위해서 고품격 지향 백화점의 경우에는 해외 제품(Made in Italy) 을 수입하여 공급하였고, Mass군 지향 백화점은 판매성과 패션성있는 제품을 공급하였다. 또한 현재 업무 기능별 시스템을 과거에는 백화점, 단독점, 대리점 운영체계에서 서울수도권, 영남권, 충호남권등 지역마케팅시스템으로 전환하였다. 이는 지역적으로 제품에 대한 패션성등의 차이를 관리시스템에 반영한 것이었다.

\section{7. 상품권 전략}

기존 상품권 중심의 매출 및 업무 구조를 브랜드중심 구조로 재편하기 위해 상품권 영업은 별도의 독립 사업부로 분리 운영하였다. IMF이후 전체 시장 규모는 확대추세이나 
제화 상품권의 MS는 감소하므로 기존 상품권의 활성화를 위한 전략을 가미하여 업종간 제휴 확산( 품목과 이용장소)하고, on-line으로 유통채널의 다양화를 꾀하였다. 이미 자체적으로 상품권 판매 인터넷 사이트를 운영중인 에스콰이아는 온라인 상품권 등 새로운 형태의 상품권 발행도 준비중이다.

또한 화장품/의류/콘도/레저 등과 공동 마케팅을 추진하였다. 한 예로, 에스콰이아는 창립 40주년을 기념해 눈 성형, 코 성형, 주름살 제거 등 성형수술 상품권을 이벤트 상품으로 내걸었다. 에스콰이아 관계자는 "에스콰이아가 지속적으로 추구해온 '여성의 세련된 아름다움'과 '뷰티', '차밍'이라는 컨셉이 이벤트와 잘 맞아 떨어져 기획됐다"며 "에스콰이아 주요 고객인 20-30대 여성을 대상으로 행사를 실시한다"고 설명했다. 또한 에스콰이아/레저업체 등과의 제휴를 확대하여 400 여 개 매장에서 사용이 가능하도록 하였다. 이처럼 에스콰이아는 사용처를 확대하는 방법으로 상품권 인기를 올리는 전략을 펼쳤다.

상품권을 원하는 고객의 다양성에 초점을 맞추어서 고객이 제품을 필요로 해서 상품권을 구입하는 시스템으로 전환하였다. 즉, 상품권이 있어서 제품을 구매하는 것이 아니라 상품이 사고 싶되 좀 더 싸게 구입하고자 상품권을 구매하도록 유도하였다. 이것은 선물용으로 대량 구입하는 기업에게는 유리한 것이었다. 상품권 고정 고객을 대상으로 다이렉트 메일을 전송하는 등 다양한 판촉 행사에도 적극적으로 나서고 있다.

\section{4. 다시 태어난 에스콰이아}

\section{1. 변화에 대한 고객 인지도}

97년 초부터 시작한 에스콰이아의 변화필요성 인식은 I MF를 거치는 과정에서 전략 변화를 시발로 약 3년의 시간이 걸려서 성과가 보이기 시작하였다. 경기에 따라 매출은 쉽게 회복될 수 있고, 이익도 날 수 있지만 가장 중요한 고객의 인식은 바꾸어지기가 쉽지 않았다. 고객 인지도가 99년에 비해 2000년도에는 $17.7 \%$ 상승한 것을 보면 고객들이 에스콰이아의 변화를 인식하기 시작한 것을 알 수 있다.

[그림 9] 소비자 변화인식

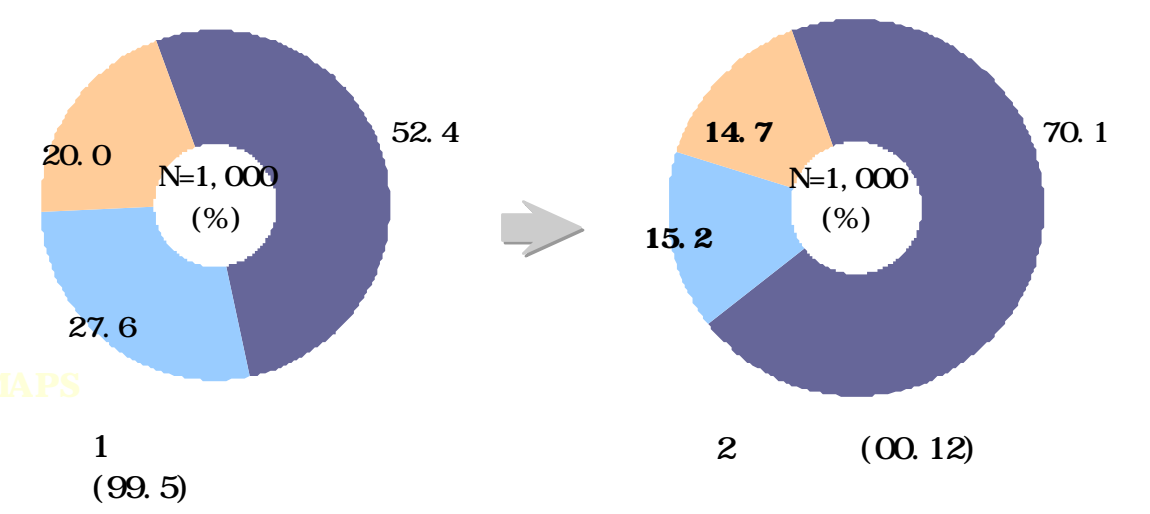




\section{2. $\mathrm{ESQ}$ 매장 출입 고객의 변화}

에스콰이아의 전략적 의사결정의 가장 중요하고 장기간 영향을 미칠 수 있는 것이 고객명확화와 마케팅전략의 정교화였다. 이는 에스콰이아 제품을 구매하는 고객이나 매장을 찾아주는 방문고객이 타겟으로 정한 고객과의 일치하는 가로 판단할 수 있다. 최근 조사에 따르면 매장 출입고객 연령 또한 변화를 보였다. 20대 고객의 출입은 증가 양상을 보이는 반면, 40 대 고객은 $12 \%$ 에서 $22 \%$ 로 $10 \%$ 의 감소추세를 보였다. 이는 에스콰이아의 고객명확화 전략이 성공을 거두고 있는 증거라고 하겠다.

[그림 10] 에스콰이아 매장 출입고객의 변화

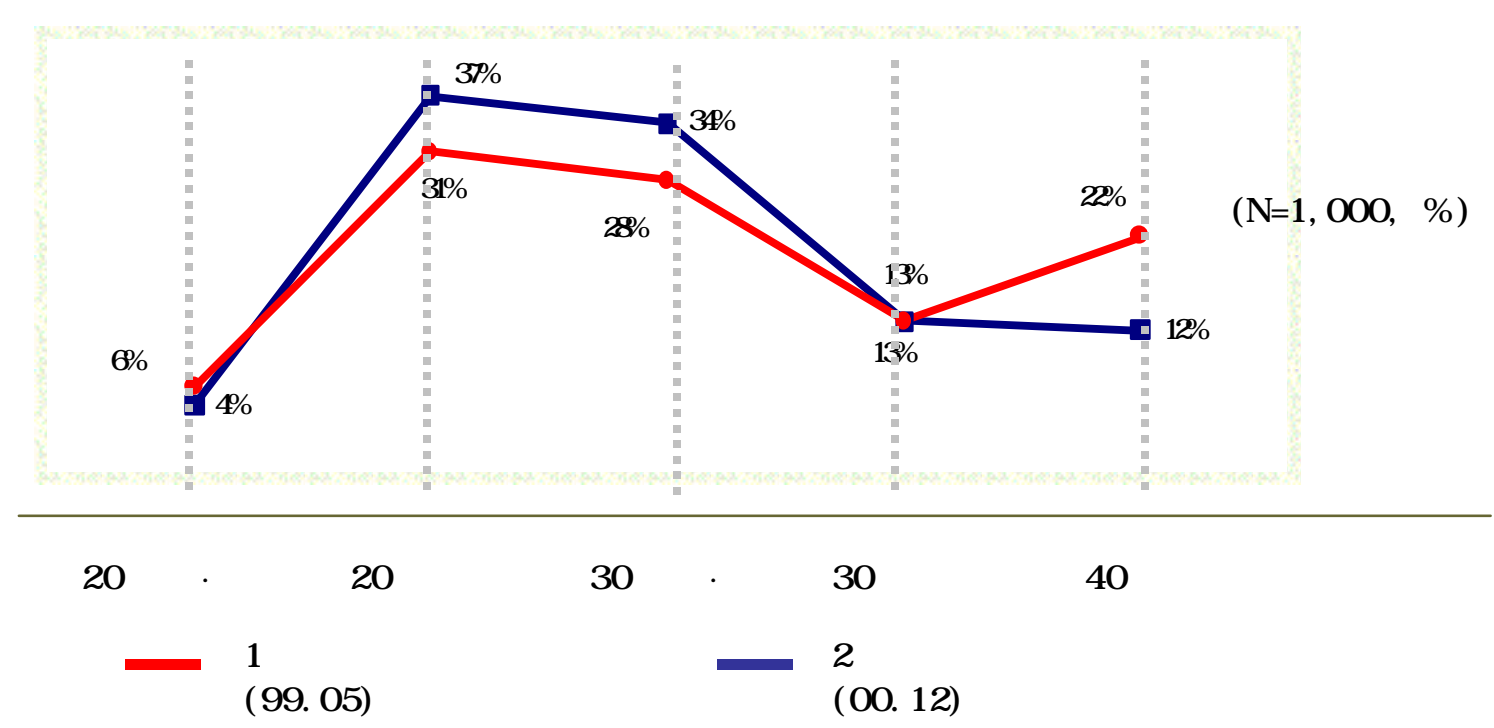

\section{3. 매출의 변화}

\section{3.1. 총 매출 흐름}

매출이 지속적으로 감소하던 추세가 98 년을 저점으로 회복세에 돌아섰다. I MF이후의 경기회복세의 힘을 받기는 했지만 그 내용면에서 보면 과거의 중장년층 위주의 매출에서 상대적인 패션 구매력이 높은 20대 후반 - 30대 여성 고객이 유입되어서 매출이 증가하였다.

[그림 11] 매출 신장추이

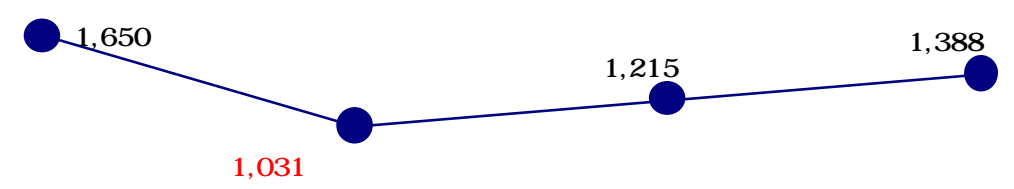




\section{3. 2. 매출의 내용변화}

매출의 증가의 의미가 또 다른 측면이 상품권 매출 비중이 감소하였다는 것이다. 상품권 매출 대신 브랜드 위상 강화에 초점을 맞춤으로서 상품권에 대한 의존도가 $70 \%$ 였던 것이 $63 \%$ 로 줄어 $7 \%$ 의 감소율을 보였다. 즉 매출 증가의 구조가 전환되어 실질적인 이익기여도는 상당히 증가하였다. 또한 패션산업에서 전형적인 세일 비중이 줄고 정상가 판매의 비중이 증가하였다.

[표 4] 상품권 비중의 감소

\begin{tabular}{|c|c|c|c|}
\hline & 1998 & 2000 & 목 표 \\
\hline 상품권 & $70 \%$ & $63 \%$ & $55 \%$ \\
\hline 현 금 & $30 \%$ & $37 \%$ & $45 \%$ \\
\hline
\end{tabular}

[ 표 5] 정상 판매의 증가

\begin{tabular}{|c|c|c|}
\hline & 1998 & 2000 \\
\hline 정상 판매 & $58 \%$ & $64 \%$ \\
\hline 세일 판매 & $33 \%$ & $26 \%$ \\
\hline 균일 덤핑 & $9 \%$ & $10 \%$ \\
\hline 계 & $100 \%$ & $100 \%$ \\
\hline
\end{tabular}

4. 3. 3. 브랜드 및 성별 판매 비중

이외에도 패션감도가 높은 20대 후반-30대 초반의 매장 입점객수의 증가에 힘입어 그들을 타겟으로 삼는 브랜드인 "Esqui re"가 매출에 호조를 보이고 있고 중장년층의 대상인 "Out$\mathrm{Cl}$ ass"는 감소추세를 보이고 있다. 결과적으로 차별적인 패션전문기업으로서의 이미지와 위상을 높이는 고객명확화 전략이 실제로 실효를 거두고 있으며, 앞서서 실행했던 전략의 대부분이 성과를 보이고 있다.

[표 6] 브랜드 판매비중

\begin{tabular}{|c|c|c|c|c|}
\hline & \multicolumn{2}{|c|}{ 성장율 } & \multicolumn{2}{c|}{ 남. 여 비중 } \\
\hline & $\mathrm{ESQ}$ & Out - Cl ass & $\mathrm{ESQ}$ & Out - Cl ass \\
\hline 남 화 & $+73 \%$ & $\triangle 15 \%$ & $50 \%$ & $70 \%$ \\
\hline 여 화 & $+66 \%$ & $\triangle 2 \%$ & $50 \%$ & $30 \%$ \\
\hline 계 & $+69 \%$ & $\triangle 12 \%$ & $100 \%$ & $100 \%$ \\
\hline
\end{tabular}

\section{4. 손익 지표 개선}

재무적인 성과를 종합해주는 손익계산서 상에서도 매출, 매출이익, 영업이익의 증가가 눈에 띄게 나타나고 있다. 판매관리비의 비중도 계속적으로 감소하고 있다. 이러한 결과는 단기적인 어려움을 극복하기 위해 수행되었던 여러가지의 전략활동들을 수행하면서 최우선 
순위를 패션업의 본질을 지키고 키워가고자 했던 마케팅노력의 결과라고 하겠다.

[ 표 7] 손익지표

\begin{tabular}{|c|r|r|r|r|r|}
\hline 구분 & \multicolumn{2}{|c|}{$98.7-99.6$} & \multicolumn{2}{|c|}{00.1 - 00.12} & 성장율 \\
\hline 영업매출 & 2,712 & & 3,171 & & $17 \%$ \\
\hline 순 매 출 & 2,170 & $100 \%$ & 2,498 & $100 \%$ & $15 \%$ \\
\hline 매출원가 & 1,238 & $57 \%$ & 1,287 & $52 \%$ & $4 \%$ \\
\hline 매출총이익 & 932 & $43 \%$ & 1,211 & $48 \%$ & $30 \%$ \\
\hline 판매관리비 & 909 & $42 \%$ & 956 & $38 \%$ & $5 \%$ \\
\hline 영업이익 & 23 & $1 \%$ & 255 & $10 \%$ & $1009 \%$ \\
\hline 영업외수익 & 49 & $2 \%$ & 57 & $2 \%$ & $16 \%$ \\
\hline 지급이자 & 324 & $15 \%$ & 142 & $6 \%$ & $-56 \%$ \\
\hline 경상이익 & $\triangle 252$ & $-12 \%$ & 170 & $7 \%$ & $167 \%$ \\
\hline
\end{tabular}

- 위의 매출은 에스콰이아/콜렉션/캐주얼/의류를 포함한 손익 지표임

\section{5. 전략의 유지 계획}

에스콰이아는 진정한 경쟁력을 갖추는 전략에서 지금까지 성공적인 결과를 보여주고 있다. 진정한 경쟁력이란 바로 패션업의 본질을 계속 지켜가는 것이며 이를 위해서는 특정 소수집단을 위한 예술적인 패션이 아니라 일반인들에 대한 마케팅이 녹아 들어있는 패션을 발전시켜가는 것이다. 이를 위해서 앞으로 에스콰이아가 현재의 전략방향을 보다 굳건히 하고 계속되는 발전을 위해서 현장과 고객에 중점을 두고 있다.

\section{1. 현장중심경영}

패션업은 다른 유통업이나 판매업과는 달리 브랜드의 매출규모나 회사의 규모에 있어서 한계가 명확한 산업이며, 이를 초과하는 경우에는 원래의 이미지를 손상하여 장기적으로는 존속하기가 힘들게 된다. 따라서 패션업의 오너나 전문경영인, 나아가서 조직자체가 패션에 대한 이해를 동일하게 하고있고 현장에 대한 감을 가지고 있어야 한다. 이를 위해서 에스콰이아는 전체의 조직을 현장과 가장 밀착할 수 있는 조직으로 개편하였으며, 각 부분별로 정기적인 현장 체험을 실시하고, 지역장 중심으로 현장 경영능력을 강화하였다. 


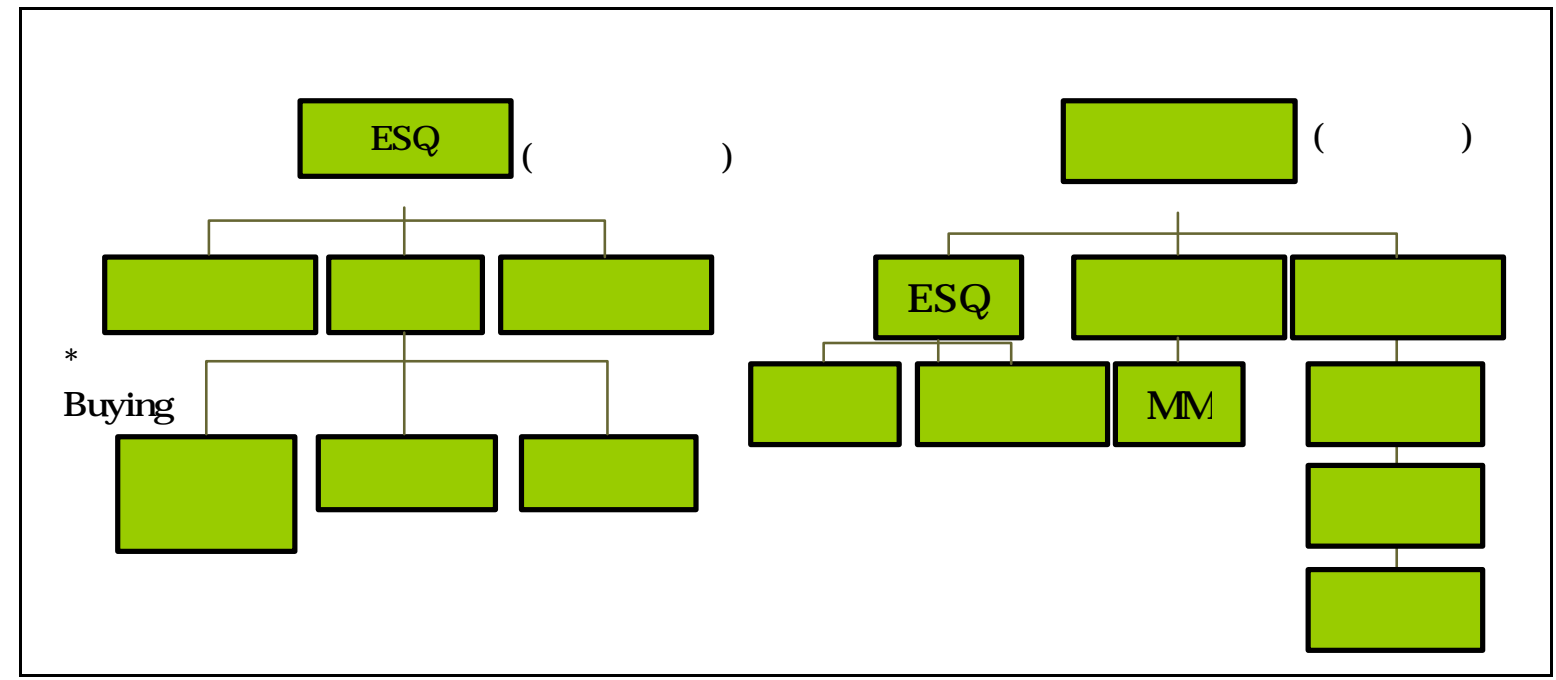

\section{2. 고객 바로 알기}

두번째로는 마케팅에 근간을 둔 패션이기 위해서 고객중심이 되어야 한다. 패션이란 예술가적인 창조성과 일상을 깨는 파격이 필요하지만, 세계적인 기업들과 같이 에스콰이아가 추구해야 하는 패션성은 고객에 기초를 두어야 한다. 따라서 고객을 제대로 알기 위한 노력을 아래와 같이 계속적으로 기울이고 있다.

1) 년2회 고객과 경쟁자에 대한 정기적인 조사를 함으로써 고객 바로 알기를 통해 시장의 새로운 기회를 발견하고 있다.

2) 고객과 현장의 소리를 주간별로 파악하는 동시에 고객과 제품에 대한 Feedback을 강화하였다. 즉, '제품과 고객'의 공감대를 일치 시켜 기존의 고객을 유지하였다.

3) 변화가 빠른 고객의 성향을 제품에 반영하여 디자인함으로써 신규 고객을 창출하였다.

4) '현재 고객'과 '브랜드 고객' 간의 bal ance를 유지하기 위해서 고객과 관련된 현장의 모든 문제를 $\mathrm{DB}$ 화하여 전직원이 공유하였다. 